\title{
Seismo-Geochemical Variations in SW Taiwan: Multi-Parameter Automatic Gas Monitoring Results
}

\author{
T.F. Yang, ${ }^{1,2}$ C.-C. Fu, ${ }^{1}$ V. Walia, ${ }^{2}$ C.-H. Chen, ${ }^{1,3}$ L.L. Chyi, ${ }^{4}$ T.-K. LiU, ${ }^{1}$ \\ S.-R. Song, ${ }^{1}$ M. LeE, ${ }^{5}$ C.-W. Lin, ${ }^{5}$ and C.-C. LiN $^{5}$
}

\begin{abstract}
Gas variations of many mud volcanoes and hot springs distributed along the tectonic sutures in southwestern Taiwan are considered to be sensitive to the earthquake activity. Therefore, a multi-parameter automatic gas station was built on the bank of one of the largest mud-pools at an active fault zone of southwestern Taiwan, for continuous monitoring of $\mathrm{CO}_{2}, \mathrm{CH}_{4}, \mathrm{~N}_{2}$ and $\mathrm{H}_{2} \mathrm{O}$, the major constituents of its bubbling gases. During the year round monitoring from October 2001 to October 2002, the gas composition, especially, $\mathrm{CH}_{4}$ and $\mathrm{CO}_{2}$, of the mud pool showed significant variations. Taking the $\mathrm{CO}_{2} / \mathrm{CH}_{4}$ ratio as the main indicator, anomalous variations can be recognized from a few days to a few weeks before earthquakes and correlated well with those with a local magnitude $>4.0$ and local intensities $>2$. It is concluded that the gas composition in the area is sensitive to the local crustal stress/ strain and is worthy to conduct real-time monitoring for the seismo-geochemical precursors.
\end{abstract}

Key words: Active faults, gas geochemical precursor, monitoring station, Taiwan.

\section{Introduction}

Since the 1960s, geochemical signals preceding significant earthquakes have been used for earthquake prediction, especially in China, Japan, the former Soviet Union, and the United States (KING, 1986; ThomAs, 1988). Gas monitoring on hydrothermal systems and fault zones has been prevailing because gas moves at a relatively high velocity within these areas (TAKAHATA et al., 1997; TOUTAIN and Baubron, 1999; Whitehead and Lyon, 1999; Heinicke and Koch, 2000). Changes in gas compositions $\left(\mathrm{H}_{2}, \mathrm{CH}_{4}, \mathrm{CO}_{2}\right.$, and noble gases, especially $\mathrm{Rn}$ and $\mathrm{He}$ ), and $\mathrm{He} / \mathrm{Ar}, \mathrm{CH}_{4} / \mathrm{Ar}, \mathrm{N}_{2} / \mathrm{Ar}$, and ${ }^{3} \mathrm{He} /{ }^{4} \mathrm{He}$ ratios, were reported to be potential

\footnotetext{
${ }^{1}$ Department of Geosciences, National Taiwan University, Taipei 106, Taiwan, R.O.C. E-mail: tyyang@ntu.edu.tw

${ }^{2}$ National Center for Research on Earthquake Engineering, NARL, Taipei 106, Taiwan, R.O.C.

${ }^{3}$ National Applied Research Laboratories, Taipei 106, Taiwan, R.O.C.

${ }^{4}$ Department of Geology, University of Akron, Akron, OH 44325-4101, U.S.A.

${ }^{5}$ Central Geological Survey, MOEA, Taipei 235, Taiwan, R.O.C.
} 
precursors (King, 1978; Sugisaki, 1978; KaWABe, 1984; SugisaKi and Sugiura, 1986; IgARASHi et al., 1995; SANO et al., 1998; FytikAs et al., 1999; TedesCo and SCARSi, 1999; ItALIANO et al., 2001; VIRK et al., 2001; CHYI et al., 2001, 2005; YANG et al., 2005, 2006; WALIA et al., 2005; 2006). Among the potential geochemical precursors, radon changes are probably the most frequently used for earthquake monitoring/predicting purposes, although radon may be significantly affected by nontectonic changes in the environment (KING, 1986). Recently, multiparameter monitoring stations with simultaneous recording of the main external parameters (e.g., atmospheric pressure, water and air temperature, soil moisture) were strongly recommended because this approach can screen out possible nontectonic factors (TouTAIN and BAUBRON, 1999).

Systematic radon monitoring, aiming at earthquake prediction, was performed continuously in northern and northeastern Taiwan in 1980s (LiU et al., 1985). However, this project was terminated in 1990 due to a shortage of funds. After the largest and most disastrous earthquake (1999 Chi-chi earthquake, $M_{W}=7.6$ ) of the 20 th century in Taiwan, a new phase of a geochemical monitoring project in southwestern Taiwan was started in 2000. Representative sites, such as mud volcanoes and hot springs, with natural gases bubbling from deep sources along tectonic suture zones were chosen for weekly sampling. Gases were collected with pre-evacuated low permeability glass bottles, and analyzed for composition and ${ }^{3} \mathrm{He} /{ }^{4} \mathrm{He}$ isotopic ratios. Results for gases from Chung-lun (CL) (Fig. 1) for two years (from July, 1999 to September, 2001) showed significant temporal variations of ${ }^{3} \mathrm{He} /{ }^{4} \mathrm{He}$ ratio before and after the earthquake (YANG et al., 2006). Hence, it was considered a candidate for further earthquake surveillance. Consequently, a multiparameter, continuous gas monitoring station, mainly equipped with a radon detector and a quadrupole mass spectrometer (QMS), was installed at the CL site since 2001. Continuous operation for more than one year demonstrates that the gas composition in this area showed significant variations. Possible effects of meteorological factors and earthquakes on the gas composition and flux are major concerns in this paper.

\section{Geological Background of the Monitoring Site}

Taiwan is situated at the boundary between the Eurasian Plate and the Philippine Sea Plate and has been subjected to an oblique collision with the northern Luzon arc in the Philippine Sea Plate since mid-Miocene (Fig. 1A). As a result of the collision by the northwestward movement of the Philippine Sea Plate, a series of thrust faults were developed in western Taiwan (Fig. 1B). The 1999 Chi-chi earthquake $\left(\mathrm{M}_{\mathrm{W}}=\right.$ 7.6) occurred along the Che-lung-pu (CLP) fault (Fig. 1C) and resulted in a surface rupture extending for $100-\mathrm{km}$ in a nearly north-south direction in front of the Western Foothills, central Taiwan (CHEN, Y.G. et al., 2001; CHEN, W.S. et al., 2003). 


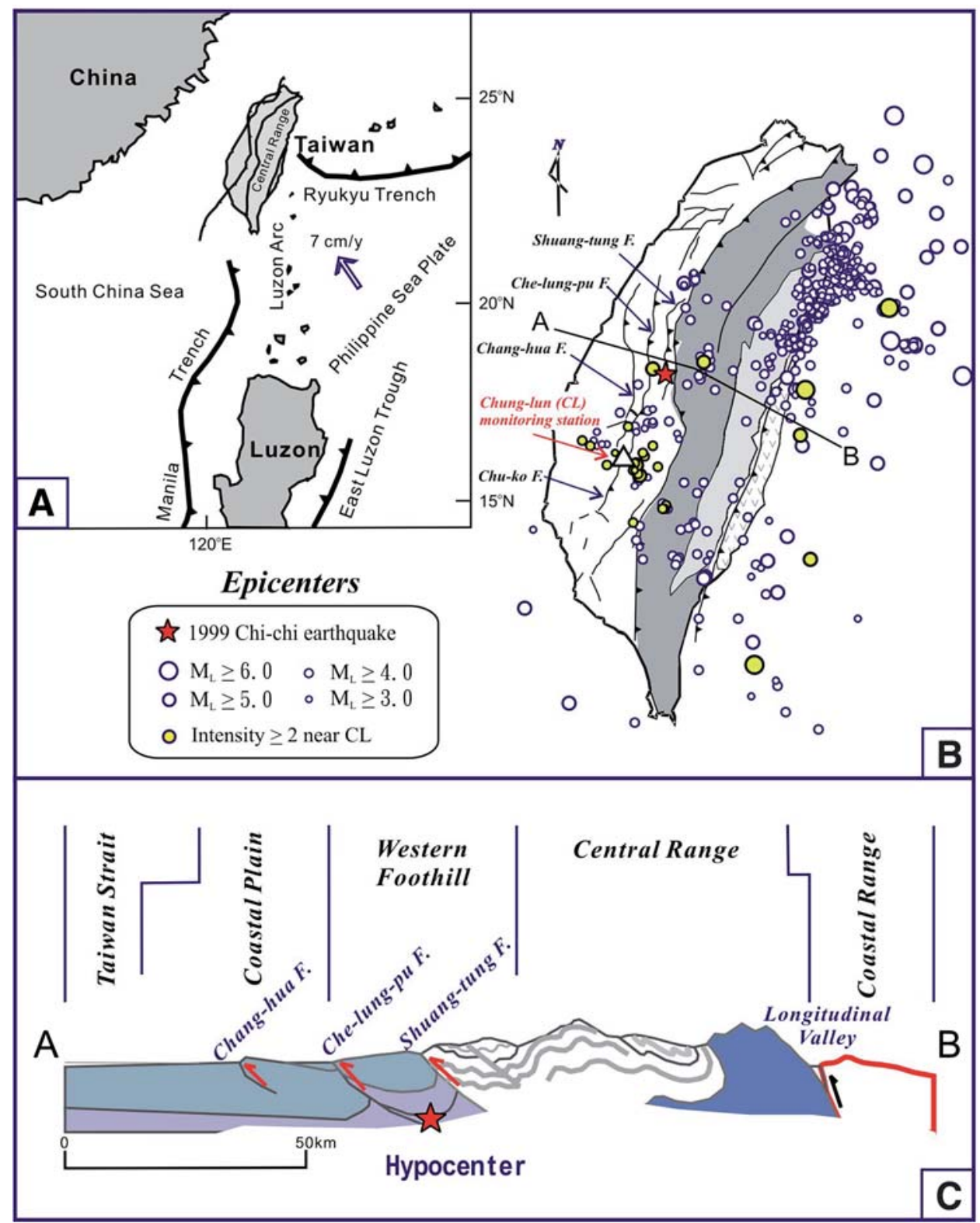

Figure 1

Tectonic settings and the earthquakes that occurred around Taiwan during the period of gas monitoring in this study. (A) Simplified tectonic features around Taiwan; (B) Distributions of the epicenters of sensible earthquakes $\left(M_{L} \geq 3.0\right)$ recorded around Taiwan from October 1, 2001 to November 30, 2002. The 1999 Chichi disastrous earthquake $\left(\mathrm{M}_{\mathrm{W}}=7.6\right)$ is also marked for reference. Those earthquakes with local intensity greater than 2 (gravity acceleration velocity $\geq 2.5$ gal) near the Chung-lun (CL) monitoring station, which is located on the Chu-ko Fault and is indicated by a triangle symbol, were marked with yellowish-color. Earthquake data are taken from the website of Central Weather Bureau, R.O.C. (http://www.cwb.gor.tw).

(C) Geologic profile along A-B cross-section shown in Figure 1B. 
The CL site is located on the culmination of an elongated anticline structure trending approximately north-northeast for a traceable length of about $15 \mathrm{~km}$. The east limb of the anticline is cut by the well-known Chu-ko (CK) thrust fault (Fig. 1B), which connects the CLP fault at the northern end and is considered to be one of the most potentially reactive faults in southwestern Taiwan. Previous geological survey showed that abundant oil or gas might have been accumulated near the CL area (CHANG, 1962). However, several test wells drilled by the Chinese Petroleum Corporation indicated that the gas composition is predominantly $\mathrm{CO}_{2}$. Reservoirs of future potential were identified in the Miocene sandstone strata, which are overlain by Miocene shales. The porosity and permeability of the sandstones can be classified as of the fair to good category (WU, 1968). In addition to the CK fault, at least three faults merge together and form a heavily fractured fault zone in this area (CHYi et al., 2001). Thus, gases of deep lithosphere origin may be able to migrate upward to the surface through the fractured pathways (YANG et al., 2003).

\section{The Monitoring Station}

Many mud volcanoes and hot springs are distributed along the tectonic sutures in southwestern Taiwan (YANG et al., 2004). The composition of gas and fluid are considered to be sensitive to the earthquake activity (CHYI et al., 2001, 2005; SonG et al., 2005, 2006; YANG et al., 2005). Hot springs $\left(\sim 70^{\circ} \mathrm{C}\right)$ and mud-pools (ambient temperature) are also found in the CL area. In terms of ${ }^{3} \mathrm{He} /{ }^{4} \mathrm{He}$ ratios, the bubbling gases are suggested to be originated from a mantle-derived component mixed with a crustal component (YANG et al., 2003). A striking feature is the large variation of gas composition associated with seismic activity (CHEN, C-H. et al., 2004; YANG et al., 2005; 2006). Meanwhile, some local people claimed that vigorous bubbling of gases in the largest mud-pool at CL often occurred several days before big earthquakes, deserving its nickname of "earthquake pond". Thus, the composition and flux variations of gases from this area may provide useful information on earthquake activity. After continuous monitoring the gas composition of CL mud-pool by manually sampling every one-two weeks from December, 2000 to June, 2001, CHEN et al. (2004) argued that the $\mathrm{CO}_{2} / \mathrm{CH}_{4}$ variations in bubbling gases were sensitive to the earthquake events (Fig. 2). Therefore, the $\mathrm{CO}_{2} / \mathrm{CH}_{4}$ ratio is used as a target parameter for further earthquake surveillance in this area. A monitoring station was built on the bank of the largest mud-pool in the CL area.

Figure 3 shows the configuration of the automated monitoring system. A stainless steel funnel, which is $1 \mathrm{~m} \times 1 \mathrm{~m}$ in cross section and covers about one third of the gas bubbling area, was installed inversely and fixed at the bottom of the mud pool. Bubbling gases were then introduced via a PVC pipe into the monitoring station. Gas flow rates, which range from 20 to 1200 liter/hour, are measured with a drum-type gas flow meter. After passing through a condensing water trap, the gases 


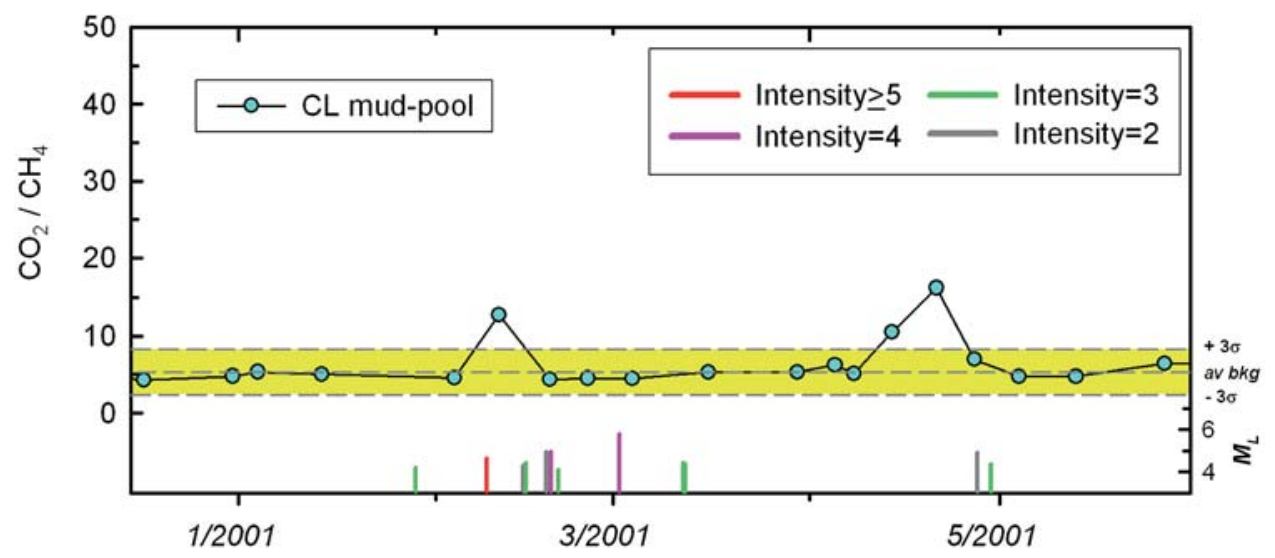

Figure 2

Variations in $\mathrm{CO}_{2} / \mathrm{CH}_{4}$ ratios of bubbling gases from the $\mathrm{CL}$ mud-pool. Earthquake data source is the same as shown in Figure 1.

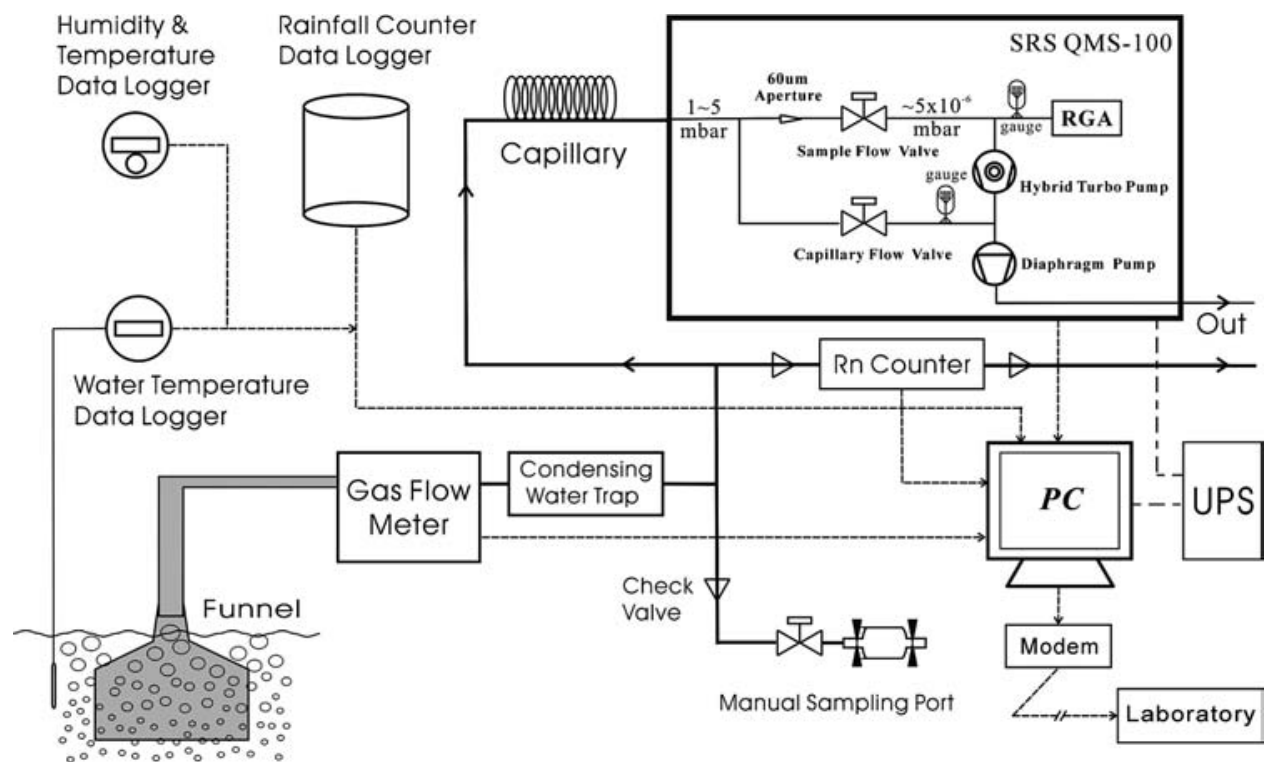

Figure 3

Configuration of the automated gas monitoring system. This system is equipped with quadrupole mass spectrometer, radon counter, drum-type gas flow meter, meteorological sensors, and an uninterrupted power supplier (UPS). Functions of each component are described in the text.

are split to (1) QMS; (2) radon counter; and (3) manual sampling port, respectively. Gas composition can be automatically analyzed by remote control. A manual sampling port, normally closed, is used for weekly sampling in order to calibrate the 
analytical systems in the laboratory. All the analytical results, including the meteorological data (humidity, air temperature, water temperature, and rainfall), can be accessed via internet.

\section{Results and Discussions}

\subsection{Temporal Variation of Gas Compositions}

After testing and calibrating for a few months, the QMS system was able to continuously analyze the composition of bubbling gases from the CL mud-pool at the interval of every two minutes. The system was set to measure $\mathrm{H}_{2}, \mathrm{He}, \mathrm{CH}_{4}, \mathrm{H}_{2} \mathrm{O}$, $\mathrm{N}_{2}, \mathrm{C}_{2} \mathrm{H}_{6}, \mathrm{O}_{2}, \mathrm{Ar}$, and $\mathrm{CO}_{2}$ simultaneously. Of these, argon and helium were measured by the channel electron multiplier (CEM) detector; and others were analyzed by the Faraday Cup (FC) detector. Figure 4 shows the hourly average of continuous recorded raw data before interference correction for the period from October 2001 to October 2002. Some abrupt changes of the time-series are due to manual factor calibration and system servicing. Significant diurnal variations of $\mathrm{H}_{2} \mathrm{O}$ are clearly related to variations in ambient temperature. Note that helium and argon concentrations appeared to decrease significantly late in the monitoring period because of the degradation of the CEM detector, although the CEM gain calibration was carried out frequently. Mass discrimination of the CEM detector can also be observed for both the helium and argon. This indicates that the CEM detector may not be as good as expected for long-term monitoring purpose, although it exhibits a much higher sensitivity and a lower detection limit than the FC detector. Meanwhile, hydrogen sensitivity is strongly affected by the temperature of the filament in the RGA analyzer. Whenever the filament was shut down and reactivated, it took a few hours for the hydrogen sensitivity to reach its original state. Helium, argon and hydrogen partial pressures may therefore not be able to represent the true composition of the sample.

To eliminate the effects of $\mathrm{H}_{2} \mathrm{O}$ variations and the abrupt change in the spectrum due to manual factor calibration of the system (Fig. 4), each component (after interference correction) was normalized to the anhydrous total pressure to represent its dry gas composition as volume percent in Figure 5. This figure shows that $\mathrm{CO}_{2}$ is the major component of the gas sample, and $\mathrm{CH}_{4}$ and $\mathrm{N}_{2}$ are the second most abundant gases. In contrast to the relative constant percentage of $\mathrm{N}_{2}, \mathrm{CO}_{2}, \mathrm{CH}_{4}$, and $\mathrm{C}_{2} \mathrm{H}_{6}$ displayed significant variations. Variations of $\mathrm{CO}_{2}$ and $\mathrm{CH}_{4}$ are negatively correlated; whereas $\mathrm{C}_{2} \mathrm{H}_{6}$ and $\mathrm{CH}_{4}$ show a positive correlation. Oxygen concentrations are relatively low $(<0.05 \%)$, consistent with the gas originated from deep sources because oxygen is a highly active gas which is easily consumed below the depth of a few meters. 

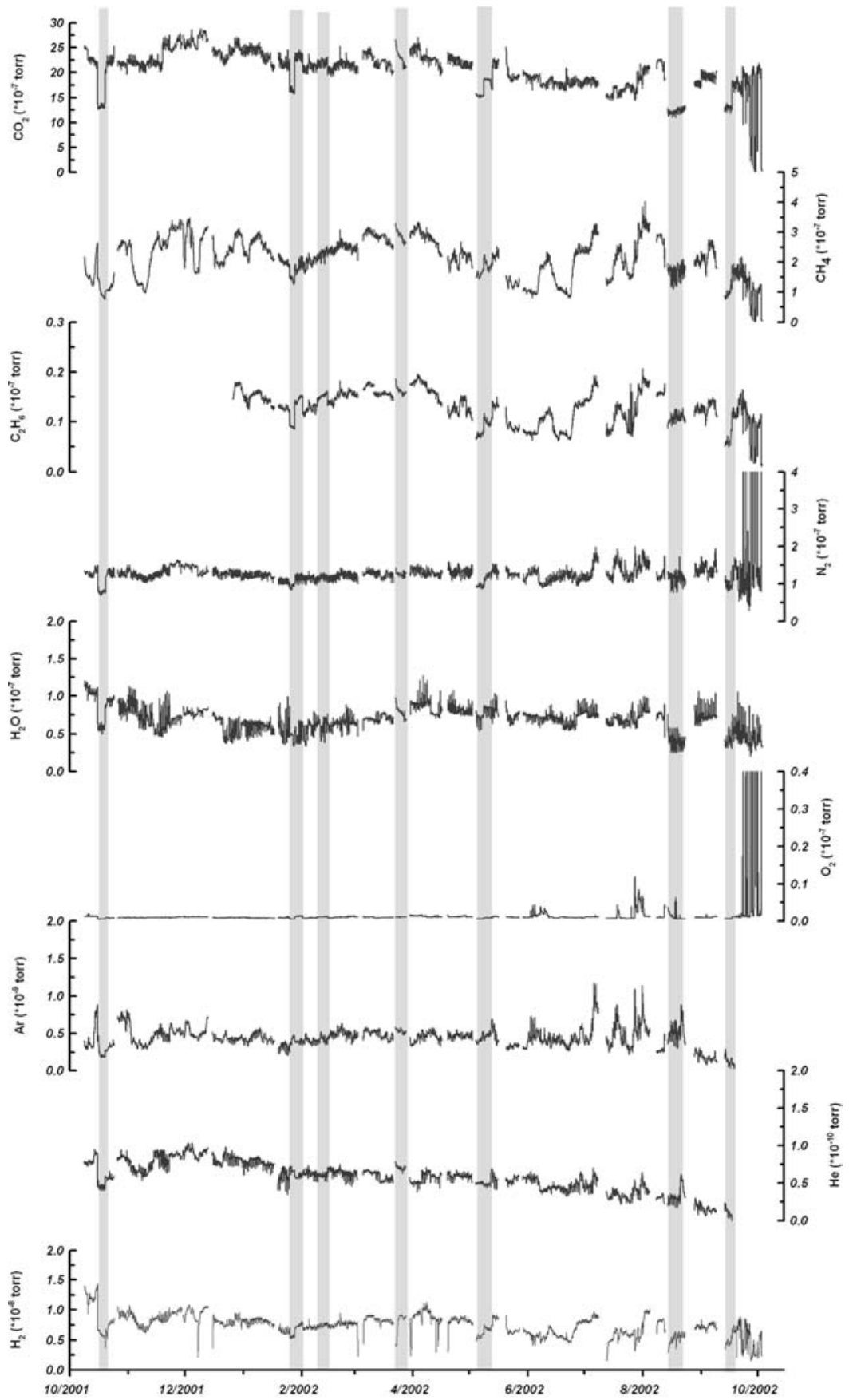

Figure 4

Continuous monitoring results of bubbling gases of the CL mud-pool. Some abrupt changes of the spectrum due to manual factor calibration and system service are marked with a grey-bar. 


\subsection{Gas Composition Affected by the Meteorological Factors}

Although air temperature and humidity are strongly correlated with the concentration of $\mathrm{H}_{2} \mathrm{O}$ in the gas sample, the meteorological factors did not affect the major components $\left(\mathrm{CO}_{2}\right.$ and $\left.\mathrm{CH}_{4}\right)$ of the bubbling gases during the dry season (Fig. 6).

$\mathrm{N}_{2}$ and $\mathrm{O}_{2}$ concentrations remained constant from October, 2001 to May, 2002, i.e., the dry season (Fig. 5). However, anomalously high $\mathrm{O}_{2}$ concentration occasionally occurred after June, 2002. Seven $\mathrm{O}_{2}$ anomalies can be recognized. Interestingly, the phenomenon is always accompanied by heavy rainfall. In contrast to the decreasing $\mathrm{CO}_{2}$ concentration, $\mathrm{CH}_{4}, \mathrm{C}_{2} \mathrm{H}_{6}, \mathrm{~N}_{2}$ and $\mathrm{Ar}$ concentrations increased suddenly in association with the first five $\mathrm{O}_{2}$ anomalies (marks a-e in Fig. 5). This implies that the local heavy rain may have disturbed the mud-pool. Consequently, the bubbling gas may be contaminated with atmospheric air and/or dissolved air $\left(\mathrm{O}_{2}, \mathrm{~N}_{2}, \mathrm{Ar}\right)$, and organic gases $\left(\mathrm{CH}_{4}\right.$ and $\left.\mathrm{C}_{2} \mathrm{H}_{6}\right)$ released from the organic-rich sediments at the bottom of the mud-pool due to the disturbance by rain water. Meanwhile, $\mathrm{CO}_{2}$ concentration decreased because of the dilution effect.

The last two $\mathrm{O}_{2}$ anomalies did not exhibit correlation with $\mathrm{CH}_{4}$ and $\mathrm{C}_{2} \mathrm{H}_{6}$ concentrations (marks f-g in Fig. 5), indicating that bottom sediments may not be disturbed. The last anomaly occurred after the heavy rain in September, 2002. This sudden heavy rain caused land sliding at the bank of the mud-pool and seriously disturbed the pool and changed the pathway of the bubbling gases. As the gas flow became very small or even close to zero, and the gas composition became dominated by atmospheric air (mark $\mathrm{g}$ in Fig. 5), it is apparent that there were no significant bubbling gases entering the gas collecting system. We were forced to stop running the monitoring system for bubbling gas then.

\subsection{Flow Rates of Bubbling Gas}

A drum-type gas flow meter (Ritter TG10 ${ }^{\circledR}$ ) was added to the monitoring system in May, 2002. The gas flow rate varied from 7 to 699 liter/hour, and was even less than 1 liter/hour after the heavy rain in September, 2002 (Fig. 5). Interestingly, radon and methane concentrations seem to be closely related to the gas flow rate. When bubbling gas flow increased significantly on July 24, 2002, radon and $\mathrm{CH}_{4}$ also increased dramatically (Fig. 7). Other major gases $\left(\mathrm{CO}_{2}, \mathrm{~N}_{2}, \mathrm{H}_{2} \mathrm{O}\right.$, and $\left.\mathrm{O}_{2}\right)$, however, did not show clear changes in concentrations. This implies that $\mathrm{CH}_{4}$ may be the major phase that carries radon gas from a deep source to the surface in this area.

To check the relationship between variations of gas concentration and gas flow rate for the $\mathrm{CL}$ mud-pool, plots for $\mathrm{CH}_{4}$ concentrations versus gas flow data recorded from May to August, 2002 were made (Fig. 8). A good correlation between them indicates that significant variations in gas flow rate may also have taken place during the dry season when meteorological effects were minimal. After a reconnaissance for possible air contamination, variations in both the gas composition and flow rate may be useful parameters for earthquake monitoring. 

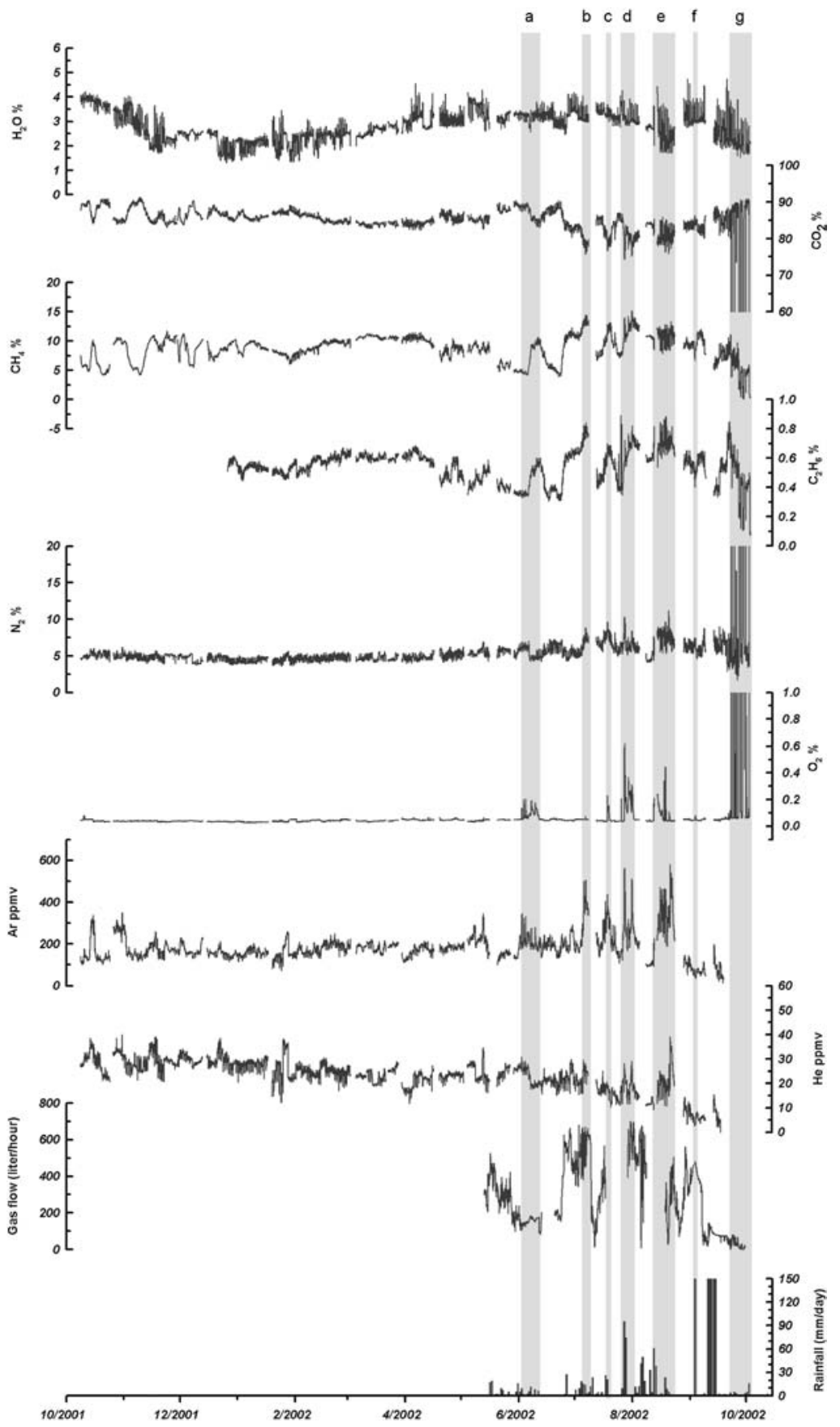

Figure 5

Temporal variations of gas compositions (volume percent) of the CL mud-pool. Anomalous high $\mathrm{O}_{2}$ contents, indicating contamination of air and/or water dissolved air, are marked. 

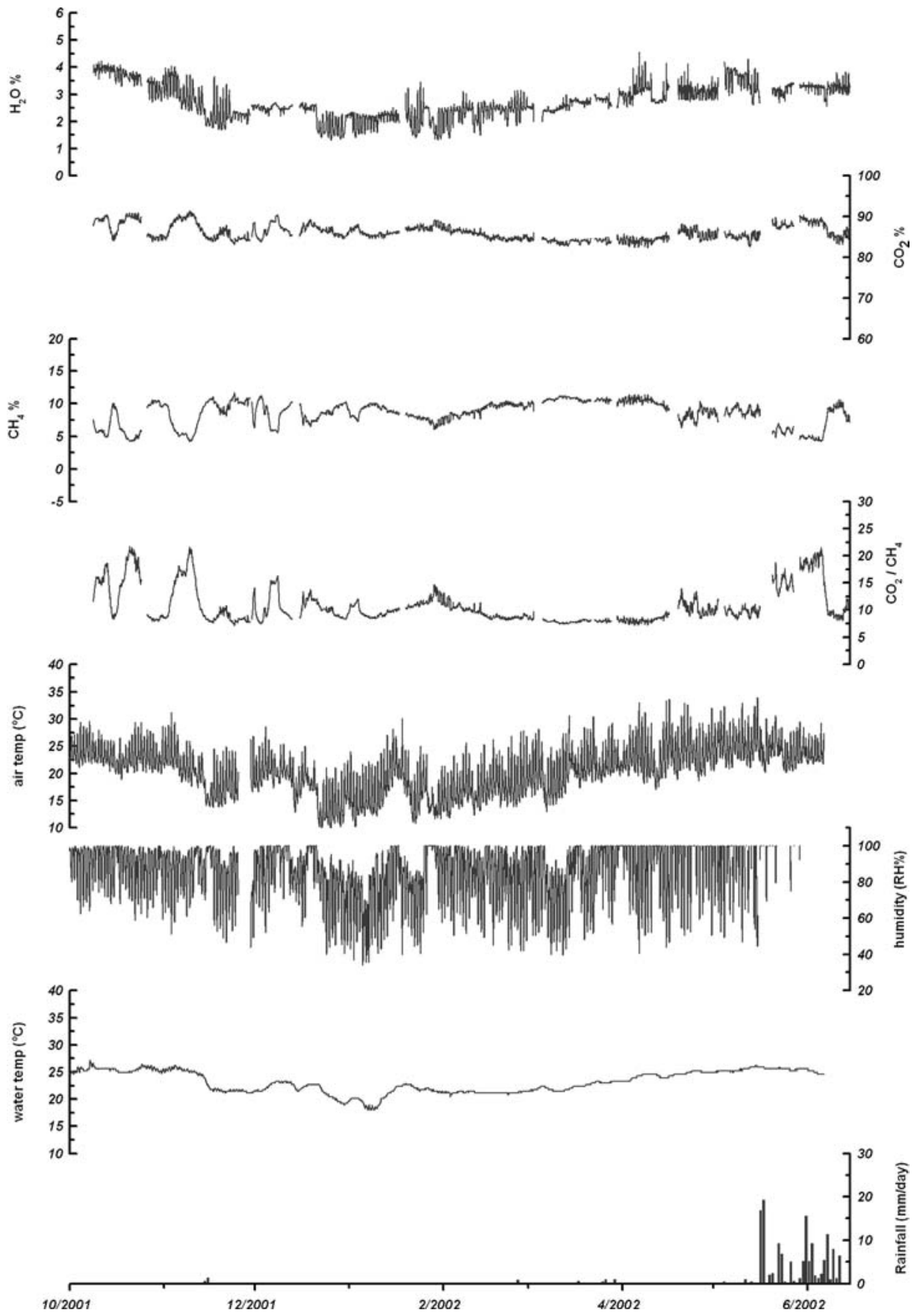

Figure 6

Variations of major compositions $\left(\mathrm{H}_{2} \mathrm{O}, \mathrm{CH}_{4}\right.$, and $\left.\mathrm{CO}_{2}\right)$ of bubbling gases and meteorological factors (ambient temperature, humidity, water temperature and rainfall) with time. There is no clear correlation between gas compositions and meteorological factors during the dry season. 


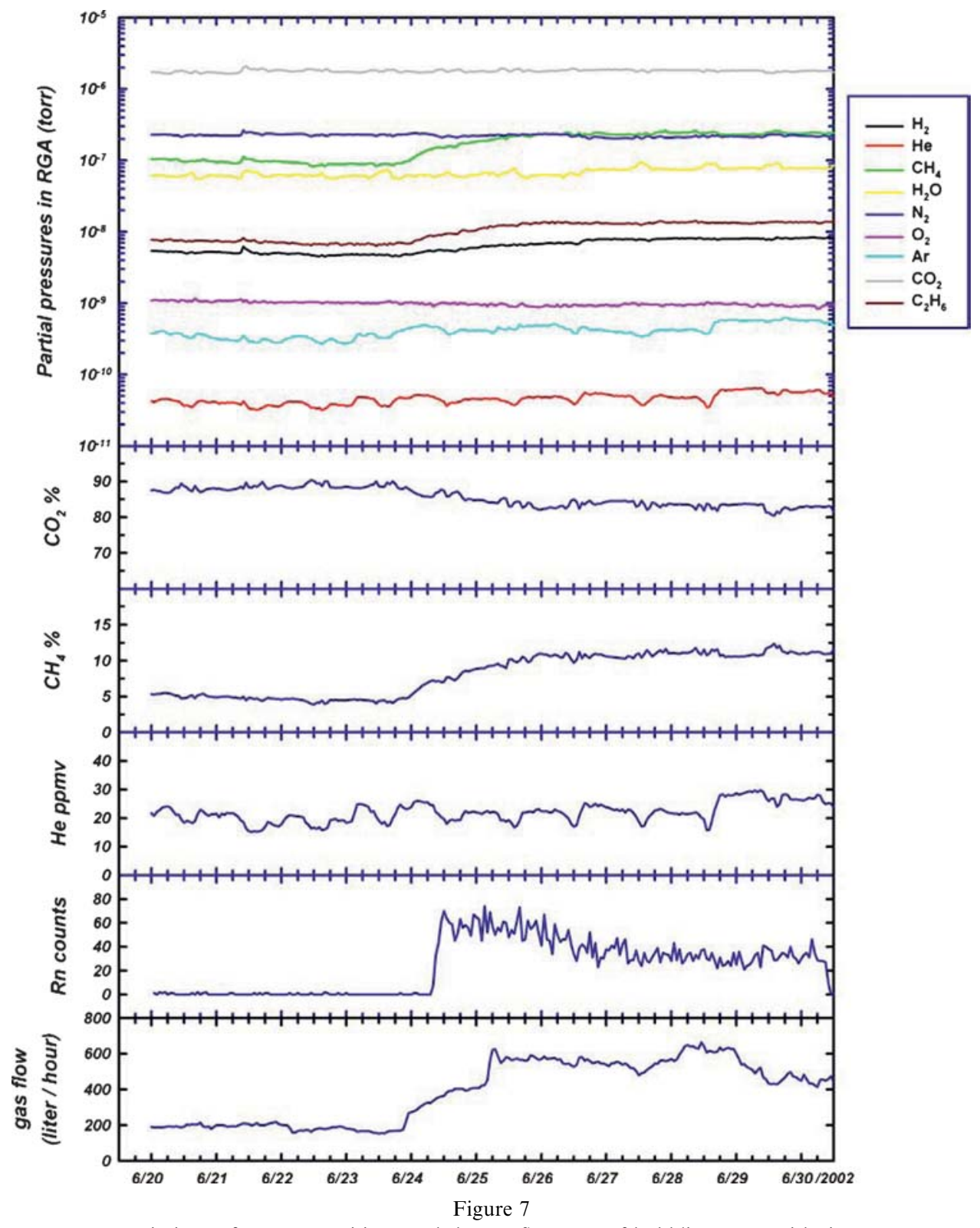

Variations of gas compositions and the gas flow rate of bubbling gases with time.

As discussed previously, the bubbling gases exhaled around the mud-pool in varying positions eventually. Hence, the measured gas flow in this study, especially during the heavy rain season (September to October, 2002), may not represent the variation of the total flux of bubbling gases in this area. 


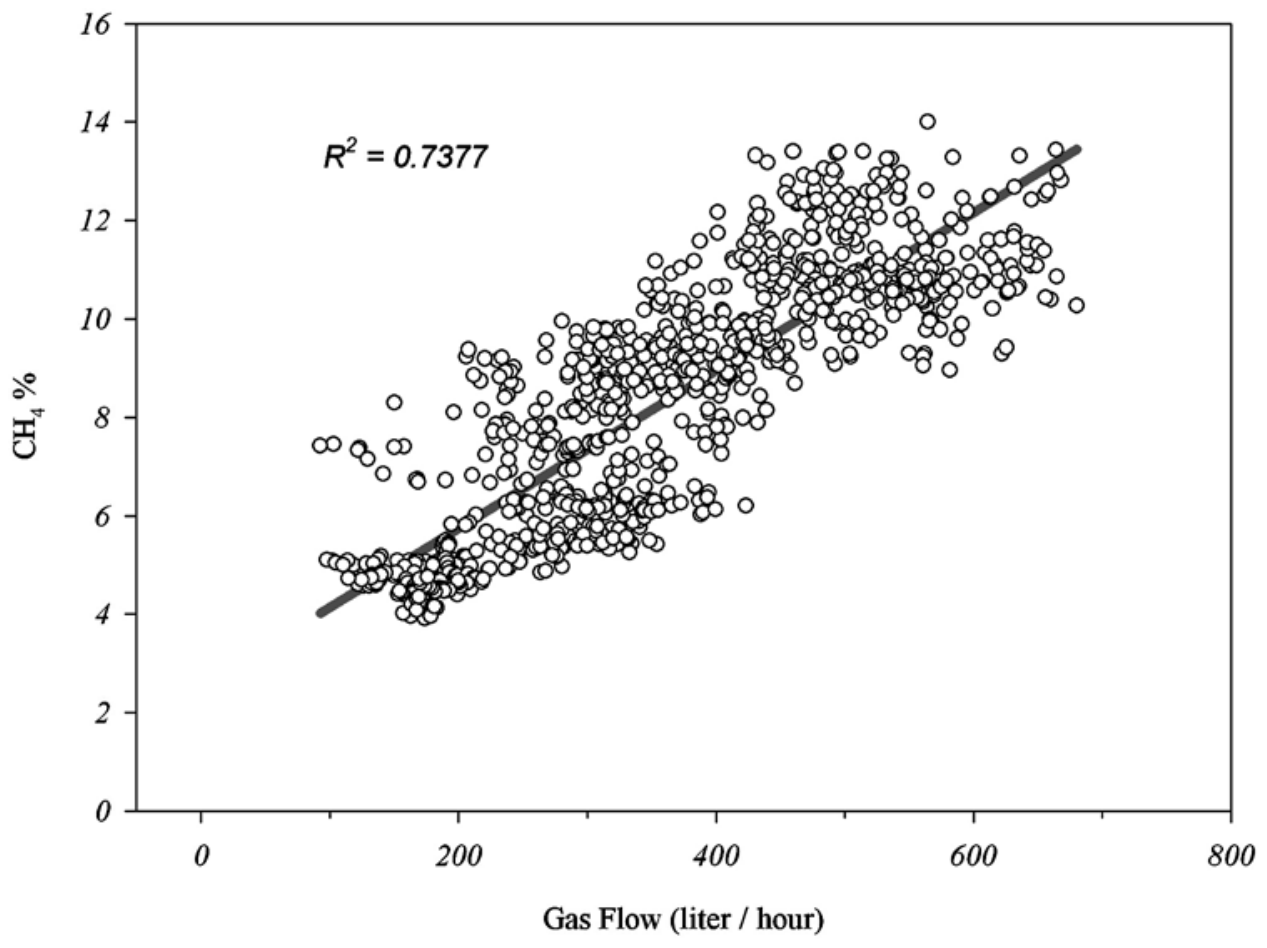

Figure 8

$\mathrm{CH}_{4}$ concentration versus gas flow plots for the CL mud-pool during the period of May 2002 to August 2002. A positive correlation between these two parameters is observed.

\subsection{Variations in Gas Compositions Associated with Earthquakes}

Disregarding sample data that may have been contaminated by the atmospheric air and/or water dissolved air due to heavy rain (those marked in Fig. 5), we are able to discuss the relationship between the gas composition and associated earthquake events (Fig. 9). Considering the variation in gas composition and the sensitivity to earthquakes, the $\mathrm{CO}_{2} / \mathrm{CH}_{4}$ ratio can amplify the individual $\mathrm{CO}_{2}$ and $\mathrm{CH}_{4}$ variations, and minimize the influence of potential air contamination (both are in trace amounts in atmospheric air). With reference to the background values shown in Figure 2, indicate a total number of 23 anomalous variation peaks can be identified for further correlation with relevant earthquakes (Fig. 9).

A total of 444 earthquakes have been recorded around Taiwan during the period, from October 1, 2001 to November 30, 2002 (Fig. 1). Twenty-five earthquake events $\left(\mathrm{M}_{\mathrm{L}} \geq 3.0\right.$ and Intensity $\left.\geq 2\right)$ were considered to be effective with respect to the monitoring site. We divide the earthquakes into three groups based on the distance between epicentres and the monitoring site (Table 1). Nineteen "effective" earthquakes 


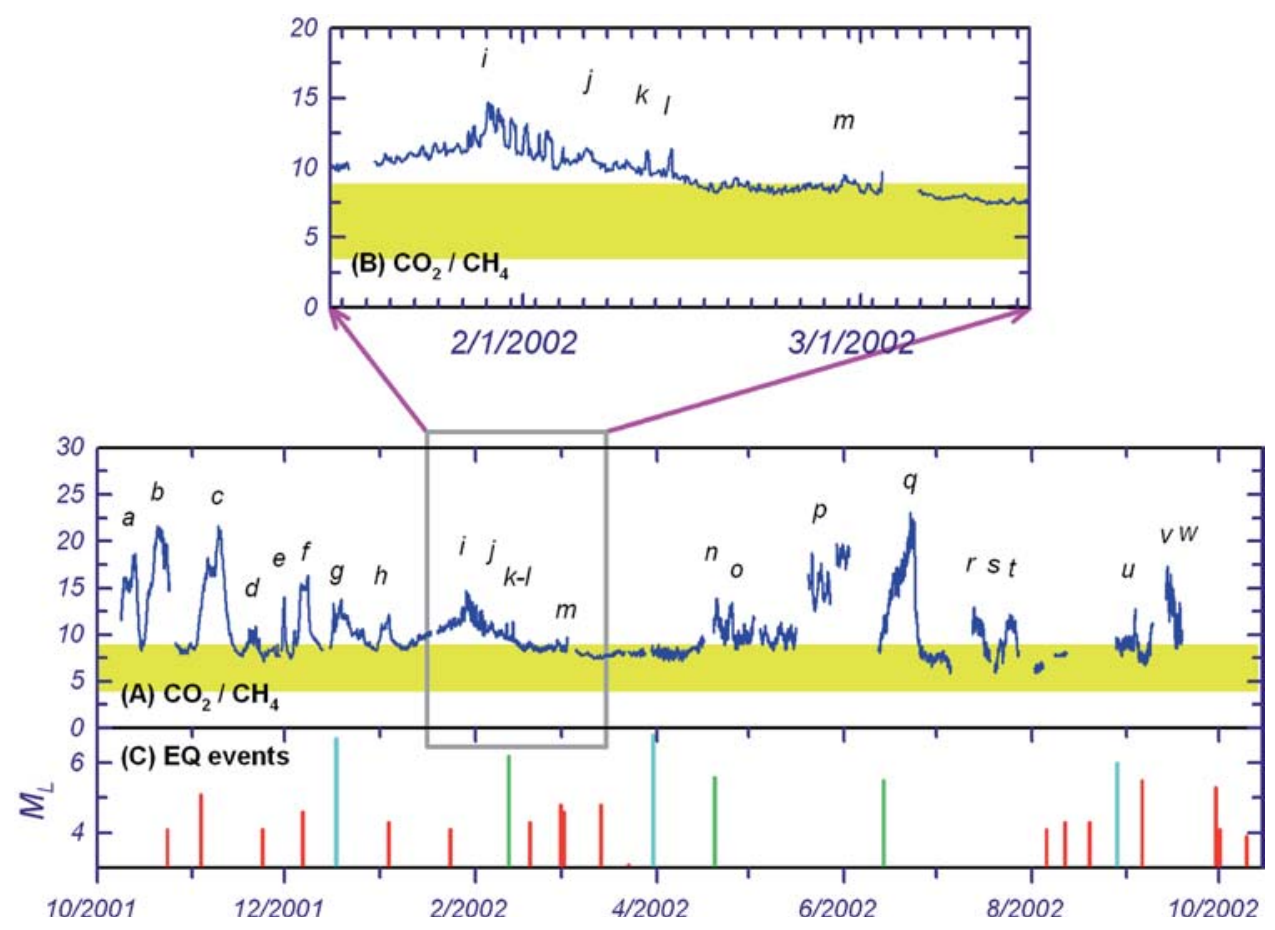

Figure 9

Variations of $\mathrm{CO}_{2} / \mathrm{CH}_{4}$ ratios of bubbling gases from the $\mathrm{CL}$ mud-pool and associated related earthquake events. (A) Twenty-three anomalous peaks (marked with letters) can be recognized; the background range was taken from Figure 2; (B) Enlarged blocked for better resolving the anomalous peaks i-m; (C) Earthquake events (data source from Fig. 1); red: group I; green: group II; blue: group III (see Table 1 for grouping).

belong to Group I (epicentres $\leq 80 \mathrm{~km})$; three earthquakes to Group II $(80-150 \mathrm{~km})$, and another three to Group III ( $\geq 150 \mathrm{~km})$, respectively. This indicates that only those earthquakes that occurred close to the monitoring site can be effective; unless the magnitude exceeded 5.5.

Aside from four earthquake events (numbers 13, 14, 20, 24), each earthquake can be correlated to one or two precursory anomalous peaks a few days to a few weeks earlier (Table 1). Earthquake 13 failed to show an associated anomaly probably due to its small magnitude $\left(\mathrm{M}_{\mathrm{L}}=3.1\right)$. On the other hand, epicenters may be too far to reflect anomalous signals for earthquakes 14 and 20 (Group III). No data were available on earthquake 24 because the system had stopped running.

In general, the $\mathrm{CO}_{2} / \mathrm{CH}_{4}$ anomalies occurred two to four weeks ahead of the earthquake and could last for a few hours to two weeks. Many studies showed that there may be good correlations between the precursory anomalies (time and duration) and the earthquakes (magnitude, depth, distance) (see compilation and 
Table 1

Catalog of related earthquakes ${ }^{1}$ occurred from October 1, 2001 to December 30, 2002 in Taiwan

\begin{tabular}{|c|c|c|c|c|c|c|c|c|c|c|c|}
\hline No. & Local time & $\begin{array}{l}\text { Lat. } \\
\left({ }^{\circ} \mathrm{N}\right)\end{array}$ & $\begin{array}{l}\text { Long. } \\
\left({ }^{\circ} \mathrm{E}\right)\end{array}$ & $\begin{array}{l}\text { Mag. } \\
\left(\mathrm{M}_{\mathrm{L}}\right)\end{array}$ & $\begin{array}{c}\text { Depth } \\
(\mathrm{km})\end{array}$ & $\begin{array}{l}\text { Dist. } \\
(\mathrm{km})\end{array}$ & Intensity & $\begin{array}{c}\Delta \mathrm{t}^{2} \\
\text { (day) }\end{array}$ & $\begin{array}{l}\Delta \mathrm{D}^{3} \\
\text { (day) }\end{array}$ & Peak $^{4}$ & Group $^{5}$ \\
\hline 1 & 2001/10/24 01:47 & 23.48 & 120.30 & 4.1 & 5.0 & 28.0 & 2 & 14.3 & 5.0 & a & I \\
\hline 2 & 2001/11/04 16:45 & 23.93 & 121.04 & 5.1 & 5.9 & 79.3 & 2 & 14.1 & 6.2 & $\mathrm{~b}$ & I \\
\hline 3 & 2001/11/24 16:15 & 23.45 & 120.35 & 4.1 & 14.9 & 22.0 & 2 & 15.1 & 10.3 & $\mathrm{c}$ & I \\
\hline 4 & 2001/12/07 16:07 & 23.09 & 120.79 & 4.6 & 3.0 & 39.3 & 2 & 17.0 & 2.2 & d & I \\
\hline \multirow[t]{2}{*}{5} & $2001 / 12 / 18$ 12:02 & 23.89 & 123.04 & 6.7 & 32.2 & 257.5 & 3 & 17.6 & 0.9 & $\mathrm{e}$ & III \\
\hline & & & & & & & & 11.3 & 5.8 & $\mathrm{f}$ & \\
\hline 6 & 2002/01/04 05:31 & 23.56 & 120.58 & 4.3 & 13.4 & 21.2 & 2 & 28.1 & 5.8 & $\mathrm{f}$ & I \\
\hline 7 & $2002 / 01 / 2418: 20$ & 23.01 & 120.61 & 4.1 & 19.5 & 40.3 & 2 & 20.4 & 3.3 & $\mathrm{~h}$ & I \\
\hline 8 & 2002/02/12 11:27 & 23.77 & 121.66 & 6.2 & 25.1 & 120.3 & 3 & 14.1 & 14.8 & $\mathrm{i}$ & II \\
\hline 9 & $2002 / 02 / 1922: 52$ & 23.45 & 120.73 & 4.3 & 9.4 & 20.2 & 2 & 13.7 & 1.6 & $\mathrm{j}$ & I \\
\hline 10 & $2002 / 03 / 01 \quad 16: 47$ & 23.11 & 120.81 & 4.8 & 5.7 & 38.9 & 2 & 18.4 & 0.3 & $\mathrm{k}$ & I \\
\hline 11 & 2002/03/02 16:48 & 23.09 & 120.80 & 4.6 & 5.0 & 39.9 & 2 & 17.5 & 0.3 & 1 & I \\
\hline 12 & $2002 / 03 / 1419: 25$ & 23.39 & 120.68 & 4.8 & 9.5 & 13.3 & 2 & 15.2 & 0.3 & $\mathrm{~m}$ & I \\
\hline 13 & 2002/03/23 01:29 & 23.41 & 120.50 & 3.1 & 4.4 & 6.7 & 2 & - & - & - & I \\
\hline 14 & $2002 / 03 / 31 \quad 14: 52$ & 24.24 & 122.17 & 6.8 & 9.6 & 189.6 & 3 & - & - & - & III \\
\hline 15 & 2002/04/20 16:47 & 22.80 & 121.69 & 5.6 & 7.0 & 131.1 & 2 & 0.1 & 5.9 & $\mathrm{n}$ & II \\
\hline 16 & 2002/06/14 15:22 & 23.51 & 121.63 & 5.5 & 24.9 & 110.0 & 2 & 16.1 & 13.1 & $\mathrm{p}$ & II \\
\hline 17 & 2002/08/06 15:20 & 23.41 & 120.67 & 4.1 & 11.4 & 12.9 & 2 & 24.4 & 3.5 & $\mathrm{r}$ & I \\
\hline 18 & $2002 / 08 / 12 \quad 04: 57$ & 23.34 & 120.45 & 4.3 & 15.1 & 10.6 & 3 & 21.2 & 0.7 & $\mathrm{~s}$ & I \\
\hline 19 & 2002/08/20 18:01 & 23.33 & 120.76 & 4.3 & 15.0 & 21.6 & 2 & 26.8 & 3.2 & $\mathrm{t}$ & I \\
\hline 20 & 2002/08/29 01:05 & 22.20 & 121.35 & 6.0 & 13.2 & 152.6 & 3 & - & - & - & III \\
\hline 21 & 2002/09/06 19:02 & 23.89 & 120.73 & 5.5 & 26.0 & 60.4 & 2 & 3.2 & 0.7 & $\mathrm{u}$ & I \\
\hline 22 & $2002 / 09 / 30 \quad 16: 35$ & 23.34 & 120.63 & 5.3 & 5.2 & 8.7 & 3 & 16.4 & 7.9 & $\mathrm{v}$ & I \\
\hline 23 & $2002 / 10 / 0107: 50$ & 23.35 & 120.62 & 4.1 & 10.8 & 7. & 3 & 13.2 & 0.9 & w & I \\
\hline 24 & $2002 / 10 / 09 \quad 23: 49$ & 23.31 & 120.62 & 3.9 & 10.9 & $9 .{ }^{7}$ & 3 & - & - & - & I \\
\hline 25 & 2002/11/08 11:41 & 23.31 & 120.61 & 4.1 & 11.2 & 9.0 & 3 & 6.4 & 9.0 & $\mathrm{x}$ & I \\
\hline
\end{tabular}

1 There were in total 444 earthquakes recorded in Taiwan during this period (Fig. 1). Only those earthquakes with local intensity $\geq 2$ are considered significant to the monitoring site.

${ }^{2}$ Time difference between peak of the anomaly and the earthquake event.

${ }^{3}$ Duration of the anomaly.

${ }^{4}$ The relevant anomalous peak marked in Fig. 9.

${ }^{5}$ The earthquakes are arbitrarily divided into three groups according to the distance between epicenter and the CL monitoring station. Group I: $\leq 80 \mathrm{~km}$; Group II: $80-150 \mathrm{~km}$; Group III: $\geq 150 \mathrm{~km}$.

discussion by TOUTAIN and BAUBRON, 1999). With only one year observation, however, the present study does not show a clear relationship between them. Continuous surveillance for a longer time is necessary to better understand the characteristics of earthquakes that truly affect the CL area.

\section{Conclusions}

(1) An automatic multi-parameter monitoring system was set-up for long-term monitoring of gas composition at Chung-lun mud-pool, SW Taiwan. Although 
oxygen is not measured for the geochemical monitoring purpose, we successfully used it as a good indicator for monitoring air-contamination in this study. Accordingly we are able to resolve possible effects of the environmental factor on gas samples.

(3) Bubbling gases from CL mud-pool is mainly composed of $\mathrm{CO}_{2}, \mathrm{CH}_{4}, \mathrm{~N}_{2}, \mathrm{H}_{2} \mathrm{O}$, and small amount of $\mathrm{C}_{2} \mathrm{H}_{6}, \mathrm{O}_{2}, \mathrm{Ar}$ and $\mathrm{He}$. After one year of continuous monitoring from October, 2001 to October, 2002, the gas composition showed systematic variations and was independent of the meteorological factors.

(4) Gas flow rate of the bubbling gases ranged from 7 to 699 liter/hour, and showed positive correlation with $\mathrm{CH}_{4}$ and radon concentrations, indicating that $\mathrm{CH}_{4}$ may be the major carrier gas for radon migrating from deep sources in this area. Unfortunately, the flow rate has been down to zero since October 2002 when bubbling gases were disturbed by the land sliding due to localy heavy rain.

(5) Compared to other gases, $\mathrm{CH}_{4}$ and $\mathrm{CO}_{2}$ showed significant variations during the monitoring period, and were considered to be related to earthquake events in this area. Taking the variations of $\mathrm{CO}_{2} / \mathrm{CH}_{4}$ ratio as the main indicator, precursory anomalies can be recognized from a few days to a few weeks before an earthquake.

\section{Acknowledgement}

We thank J.H. Jiang, Y.J. Lu, D.R. Hsiao, K.W. Wu for helping in setting up and calibrating the system; L.C. Huang and W.J. Lin for providing local logistical help; Dr. W.S. Chen for providing local geological information and profile. The senior author also benefited from discussions with Dr. J. Heinicke regarding gas flow measurements. Drs. N. Perez, H. Armannsson, W.C. Evans, P. Theodorsson and one anonymous reviewer gave critical comments and improve the manuscript. This research was supported by the Central Geological Survey of Taiwan, ROC (90EC2A380103, 5226902000-01-92-01, 5226902000-02-93-01).

\section{REFERENCES}

CHAng, S.S.L. (1962), Subsurface geology of the CL-1 Wildcat, Chunglun Structure, Chiayi, and the TK-1 Wildcat, Tishuikan structure, Kaohsiung, Taiwan, Petrol. Geol. Taiwan 1, 51-65.

Chen, C-H., Yang, T.F., Song, S.R., LiU, T.K., and Lee, C.Y. (2004), Environmental geochemistry with respect to the fault activities during 2000-2002 in Chiayi-Tainan and Hsinchu-Miaoli areas, Western Taiwan, Bull. Cent. Geol. Survey 17, 129-174. (in Chinese with English abstract)

Chen, W.S., Chen, Y.G., Shin, R.C., Liu, T.K., Huang, N.W., Lin, C.C., Sung, S.H., and Lee, K.J. (2003), Thrust-related river terrace development in relation to the 1999 Chi-Chi earthquake rupture, Western Foothills, Central Taiwan, Jour. Asian Earth Sci. 21(5), 473-480.

Chen, Y.G., Chen, W.S., Lee, J.C., Lee, Y.H., Lee, C.T., Chang, H.C., and Lo, C. H. (2001), Surface rupture of the 1999 Chi-Chi earthquake yields insights on the active tectonics of Central Taiwan, Bull. Seismol. Soc. Am. 91, 977-985. 
Chyi, L.L., Chou, C.Y., YAng, T.F., and Chen, C-H. (2001), Continuous Radon measurements in faults and earthquake precursor pattern recognition, West. Pacific Earth Sci. 1(2), 227-246.

Chyi, L.L., Quick, T.J., YAnG, T.F., and Chen, C-H. (2005), Soil gas Radon spectra and earthquakes, Terr. Atmos. Oceanic Sci. 16, 763-774.

Fytikas, M., Lombardi, S., Papachristou, M., Pavlides, S., Zouros, N., and Soulakellis, N. (1999), Investigation of the 1967 Lesbos (NE Aegean) earthquake fault pattern based on soil-gas geochemical data, Tectonophysics 308, 249-261.

Heinicke, J. and Koch, U. (2000), Slug flow - A possible explanation for hydrogeochemical earthquake precursors at Bad Brambach, Germany, Pure Appl. Geophys. 157, 1621-1641.

Igarashi, G., Saeki, S., Takahata, N., Sumikawa, K., Tasaka, S., Sasaki, Y., Takahashi, M., and SANO, Y. (1995), Groundwater Radon anomaly before the Kobe earthquake in Japan, Science 269, $60-61$.

Italiano, F., Martinelli, G. and Nuccio, P.M. (2001), Anomalies of mantle-derived helium during the 1997-1998 seismic swarm of Umbria-Marche, Italy, Geophys. Res. Lett. 28, 839-842.

KAWABE, I. (1984), Anomalous changes of $\mathrm{CH}_{4} / \mathrm{Ar}$ ratio in subsurface gas bubbles as seismo-geochemical precursors at Matsuyama, Japan, Pure Appl. Geophys. 122, 194-214.

KING, C.Y. (1978), Radon emanation on San Andreas Fault, Nature 271, 516-519.

KING, C.Y. (1986), Gas geochemistry applied to earthquake prediction: An overview, J. Geophys. Res. 91, $12269-12281$.

LiU, K.K., YuI, T.F., YeH, Y.H., TsAI, Y.B., and Teng, T. (1985), Variations of Radon content in ground waters and possible correlation with seismic activities in Northern Taiwan, Pure Appl. Geophys. 122, 231244.

Sano, Y., Takahata, N., Igarashi, G., Koizumi, N., and Sturchio, N.C. (1998), Helium degassing related to the Kobe earthquake, Chem. Geol. 150, 171-179.

Song, S.R., Chen, Y.L., Liu, C.M., Ku, W.Y., Chen, H.F., Liu, Y.J., Kuo, L.W., Yang, T.F., Chen, C-H., LIU, T.K., and LEE, M. (2005), Hydrochemical changes in spring waters in Taiwan: Implications for evaluating sites for earthquake precursory monitoring, Terr. Atmos. Oceanic Sci. 16, 745-762.

Song, S.R., Ku, W.Y., Chen, Y.L., Liu, C.M., Chen, H.F., Chan, P.S., Chen, Y.G., Yang, T.F., Chen, C-H., LIU, T.K., and LEE, M. (2006), Hydrogeochemical anomalies in the springs of the Chiayi Area in West-central Taiwan as possible precursors to earthquakes, Pure Appl. Geophys. 163, DOI 10.1007/ s00024-006-0046-x.

Sugisaki, R. (1978), Changing $\mathrm{He} / \mathrm{Ar}$ and $\mathrm{N}_{2} /$ Ar ratio of fault air may be earthquake precursors, Nature 275, 209-211.

Sugisaki, R. and Sugiura, T. (1986), Gas anomalies at three mineral springs and a fumarole before an inland earthquake, Central Japan, J. Geophys. Res. 91, 12296-12304.

Takahata, N., Igarashi, G., and SAno, Y. (1997), Continuous monitoring of dissolved gas concentrations in groundwater using a quadrupole mass spectrometer, Appl. Geochem. 12, 377-382.

Tedesco, D. and Scarsi, P. (1999), Chemical ( $\left.\mathrm{He}, \mathrm{H}_{2}, \mathrm{CH}_{4}, \mathrm{Ne}, \mathrm{Ar}, \mathrm{N}_{2}\right)$ and isotopic ( $\mathrm{He}, \mathrm{Ne}, \mathrm{Ar}, \mathrm{C}$ ) variations at the Solfatara Crater (Southern Italy): Mixing of different sources in relation to seismic activity, Earth Planet. Sci. Lett. 171, 465-480.

Thomas, D. (1988), Geochemical precursors to seismic activity, Pure Appl. Geophys. 126, 241-265.

Toutain, J P. and BAubron, J.C. (1999), Gas geochemistry and seismotectonics: A review, Tectonophysics $304,1-24$.

Virk, H.S., Walia, V., and Kumar, N. (2001), Helium/Radon precursory anomalies of Chamoli earthquake, Garhwal Himalaya, India, J. Geodynam. 31, 210-210.

WALIA, V., VIRK, H.S., and BAJWA, B.S. (2006), Radon precursory signals for some earthqaukes of magnitude $>5$ occurred in N-W Himalaya, Pure Appl. Geophys. 163, DOI 10.1007/s00024-006-0044-z.

Walia, V., Virk, H.S., Yang, T.F., Mahajan, S., Walia, M., and Bajwa, B.S. (2005), Earthquake prediction studies using Radon as a precursor in $N-W$ Himalayas, India: A case study, Terr. Atmos. Oceanic Sci. 16, 775-804.

WhiteheAd, N.E. and Lyon, G.L. (1999), Application of a new method of searching for geochemical changes related to seismic activity, Appl. Radia. Isotop. 51, 461-474.

Wu, F.T. (1968), Petrographic study of oil sands of the Chunglun Structure, Chiayi, Taiwan, Petrol. Geol. Taiwan 6, 183-195. 
Yang, T.F., Chou, C.Y., Chen, C-H., Chyi, L.L., and JiAng, J.H. (2003), Exhalation of Radon and its carrier gases in SW Taiwan. Radiat. Meas. 36, 425-429.

YAng, T.F., Hsien, P.S., Chen, Y.G., and Chen, C-H. (2006), Anomalous helium isotopic variations of fluid samples before and after the 1999 Chi-Chi earthquake in SW Taiwan, Geophy. Res. Lett. (submitted)

Yang, T.F., Walia, V., Chyi, L.L., Fu, C.C., Chen, C-H., Liu, T.K., Song, S.R., Lee, C.Y., and LeE, M. (2005), Variations of soil Radon and Thoron concentrations in a fault zone and prospective earthquakes in SW Taiwan, Radiat. Meas. 40, 496-502.

Yang, T.F., Yeh, G.H., Fu, C.C., Wang, C.C., Lan, T.F., Lee, H.F., Chen, C-H., Walia, V., and Sung, Q.C. (2004), Composition and exhalation flux of gases from mud volcanoes in Taiwan, Environ. Geol. 46, 1003-1011.

(Received: June 2, 2003; revised: November 23, 2005; accepted: November 30, 2005)

Published Online First: March 28, 2006

To access this journal online:
http://www.birkhauser.ch

